\title{
Multimorbidity due to chronic noncommunicable diseases in older adults: a population-based study
}

Bruna Cardoso Leite' $\mathbb{1 D}$

Danielle Samara Tavares de Oliveira-Figueiredo' (DD

Fabiana Lucena Rocha ${ }^{\mathbb{D}}$ Matheus Figueiredo Nogueiral ID

\section{Abstract}

Objective: To estimate the prevalence of multimorbidity arising from chronic noncommunicable diseases among older residents of the northeast of Brazil and to analyze its association with sociodemographic, behavioral and anthropometric factors. Method: A cross-sectional study was carried out with 3,141 older participants of the National Health Survey (2013). The dependent variable was multimorbidity, and the independent variables were sociodemographic, behavioral and anthropometric indicators. Descriptive, bivariate analyzes and logistic regression models were applied. Results: The prevalence of multimorbidity was $23.7 \%$, with the state of Alagoas having the highest prevalence $(27.2 \%)$. The occurrence of multimorbidity was associated with the female sex $(\mathrm{OR}=1.33 ; p=0.002)$, age over 80 years $(\mathrm{OR}=1.35 ; p=0.019)$ and being overweight $(\mathrm{OR}=1.37 p=0.001)$. The protective factors were brown skin color $(\mathrm{OR}=0.79 ; p=0.013)$ and low weight $(\mathrm{OR}=0.71 ; p=0.017)$. Conclusion: The prevalence of multimorbidity in community-dwelling older adults in the northeast of Brazil was almost one quarter of the study population, with the state of Alagoas having the highest prevalence. Sex, age, skin color and being overweight were associated with the outcome. Knowledge of these factors can guide health care in the prevention, control and reduction of complications of these diseases, and support the strengthening of health education strategies and policies.
Keywords: Aging. Chronic Disease. Multimorbidity.

\footnotetext{
Universidade Federal de Campina Grande, Unidade Acadêmica de Enfermagem, Cuité, PB. Brasil.

2 Universidade Federal de Campina Grande, Unidade Acadêmica Escola Técnica de Saúde de Cajazeiras, Cajazeiras, PB, Brasil.
}

The authors declare there are no conflicts of interest in relation to the present study.

No funding was received in relation to the present study. 


\section{INTRODUCTION}

While aging is not synonymous with illness, among older adults there is an increase in clinicalfunctional vulnerability and a predisposition to chronic non-communicable diseases (CNCDs), which are associated with disabilities which in turn can increase socioeconomic burdens and elevate costs and the use of health services ${ }^{1,2}$.

CNCDs are the main global cause of morbidity and mortality ${ }^{2}$. Among them, four groups stand out: cardiovascular diseases, responsible for $29.7 \%$ of mortalities in Brazil; neoplasms, responsible for $16.8 \%$; chronic respiratory diseases, representing $5.9 \%$; and diabetes, the prevalence of deaths of which is $5.1 \% \%^{3}$.

Around $80 \%$ of the cases of these pathologies could be avoided with changes in behavioral factors. Thus, investment in strategies for reversing the alarming profile of mortality and disability due to these conditions is essential, and studies of the factors associated with the occurrence of these outcomes are essential $l^{4,5}$.

Older adults often have two or more diseases occurring simultaneously, an occurrence known as "multimorbidity", which is the main cause of death and disability in this population ${ }^{6}$. Most previous studies with this group, however, have aimed to evaluate the factors associated with each chronic disease in isolation ${ }^{7,8}$.

In addition, there are few studies with samples distributed across all the states of the Brazilian northeast and, among existing surveys, the majority demonstrated little external validation, being concentrated in only a single state or municipality ${ }^{9,10}$. While most of the research carried out with older adults is concentrated in the south and southeast of Brazi $^{19,10}$, the social inequalities that exist between the regions of the country can result in differences between unfavorable health outcomes, including multimorbidity ${ }^{11}$.

From this perspective, studies of the occurrence of multimorbidity due to CNCD and its associated factors in a sample of older adults distributed in all the states of the Brazilian northeast are required, in order to provide knowledge about the distribution of such illnesses in the region, as well as the modifiable factors that can be targeted by interventions by professionals, health managers and public policies. Thus, the aim of this study was to estimate the prevalence of multimorbidity due to CNCDs in older adults living in the northeast of Brazil and to analyze its association with sociodemographic, behavioral and anthropometric factors.

\section{METHOD}

A cross-sectional study was performed, which used secondary data from the National Health Survey (or PNS), carried out between 2013 and 2014, the data of which are available for public and free access on the website of the Brazilian Institute of Geography and Statistics (or IBGE): http://www.ibge.gov.br. The PNS consists of a home-based epidemiological survey, the general objective of which was to obtain information on the health conditions and lifestyle of the Brazilian population ${ }^{12}$.

The population that participated in the PNS survey was composed of residents of permanent private households across the country, which was divided into census tracts. Areas such as: indigenous villages, barracks, military bases, settlements, camps, boats, penitentiaries, penal colonies, prisons, jails, asylums, orphanages, convents and hospitals were excluded $^{13,14}$.

The sampling by clusters occurred in three stages: the census sectors were established as Primary Analysis Units (PAU); households as Secondary Analysis Units (SAU) and residents aged 18 years or older as Tertiary Analysis Units (TAU) ${ }^{12}$.

In the first stage, the census sectors that formed the PAUs were obtained by means of a Master Sample, which is used to meet the needs of several surveys that make up the IBGE Integrated Home Research System ${ }^{14}$. A total of 6,069 UPAs were randomly selected throughout Brazi $1^{13}$. 
In the second stage, a fixed number of households in each PAU was selected by Simple Random Sampling. The selection of households was made based on the National Address Register for statistical purposes, in the latest version available in 2013, before the completion of this stage of the sample plan, with 64,348 households visited throughout Brazil $^{13}$. Finally, in the third stage, only the selected resident could participate in the individual interview, and other members of the household were not permitted to answer the questions ${ }^{14}$.

A total of 60,202 individual interviews were carried out with the selected residents in their homes, of which 11,177 were with older adults. The sample used in this investigation was 3,394 older adults living in the states of the northeast of Brazil, namely: Alagoas, Pernambuco, Paraíba, Rio Grande do Norte, Sergipe, Bahia, Piauí, Maranhão and Ceará. Due to the presence of missing values in the variables that made up the outcome, the final sample was 3,141. Interviews in which the head of household or resident who responded to the second stage of selection, rather than the older adult, were not included.

The questionnaire was applied by IBGE collection agents, with the help of handheld microcomputers ${ }^{14}$. In the present study, data from the following modules were used: general characteristics of residents (module C), educational characteristics of people aged 5 or over (module D), lifestyle (module P) and chronic diseases (module Q).

The outcome variable was 'multimorbidity', defined as the simultaneous occurrence of two or more $\mathrm{CNCDs}^{6,15}$, which included the self-reported diagnosis of the following conditions: diabetes, heart disease (infarction, angina and congestive heart failure), systemic arterial hypertension, strokes, cancer, chronic obstructive pulmonary disease, chronic kidney disease and asthma. Multimorbidity was identified through the creation of a variable sum of these eight chronic diseases and was then dichotomously categorized as: $0=$ none or one chronic diseases and $1=$ two or more chronic diseases.

The following sociodemographic exposure variables were used: gender ( 0 - male; 1 - female); age group: (0 - 60 to $69 ; 1-70$ to $79 ; 2$ - 80 or more); level of education in years of schooling ( 0 - 12 or more; 1 - 9 to 11 years and, 2 - 0 to 8 years of study); receives pension ( 0 - yes; 1 - no); self-reported skin color (0 - white; 1 - brown (mixed ethnicity); 2 - black (Afro-Brazilian); 3 - other [yellow (Asian-Brazilian) and indigenous]); marital status: (0 - has partner; 1 - no partner).

Regarding lifestyle, the following variables were analyzed: regular consumption of fruits, salads and cooked vegetables ( 0 - consumes 5 or more times a week; 1 - consumes less than 5 times a week); practice of physical activity today (0 - yes; 1 - no); current smoking ( 0 - no; 1 - yes); current alcohol consumption $(0-\text { no; } 1 \text { - yes })^{16}$.

Anthropometry was assessed by BMI, which was calculated as weight in $\mathrm{Kg}$, divided by the height measured in centimeters, squared ${ }^{17}$. For the BMI, the cutoff points established by Lipschitz ${ }^{18}$ were used, which take into account the physiological changes resulting from senescence. Older adults with a BMI between 22 and $27 \mathrm{Kg} / \mathrm{m}^{2}$ were considered normal weight, those whose BMI was less than or equal to $22 \mathrm{Kg} / \mathrm{m}^{2}$ were considered underweight and those with a BMI greater than $27 \mathrm{~kg} / \mathrm{m}^{2}$ were overweight ${ }^{18}$.

For data analysis, a descriptive and exploratory stage of the exposure and outcome variables was performed. Simple and percentage frequency measures were used with their respective 95\% confidence intervals. Subsequently, bivariate analysis was performed. The associations of the independent variables with the outcome were verified using Pearson's chi-squared test, and the measure of association using non-adjusted odds ratios (OR). In Pearson's chi-squared test, variables with a $p$-value $<0.20$, were selected for multiple analysis.

The multiple analysis was performed by means of multiple logistic regression. For this purpose, the forward criterion was used in which all the variables selected in the bivariate step were inserted one by one in the model. The introduction of the variables began with the outcome and then the exposures of interest. The variables that remained significant, with $p<0.05$, according to the Wald test, made up the final (adjusted) model. The magnitude of association was measured by the odds ratio adjusted for confounding factors.

\section{.}


This research used secondary PNS data, which are available in the public domain. As the confidentiality and anonymity of participants were maintained, they could not be identified through data manipulation. Thus, the present study meets the requirements of Resolution 466/12 of the National Health Council. The PNS received approval from the Research Ethics Committee, under opinion number 328.159.

\section{RESULTS}

Table 1 shows that there was a predominance of older women (60.7\%), aged 60 to 69 years $(54.7 \%)$, with brown skin color/mixed ethnicity (55\%), who had 0 to 8 years of schooling $(80.5 \%)$ and retired $(79.5 \%)$.

Figure 1 shows that the prevalence of multimorbidity in older adults in the northeast was $23.7 \%$ and that the state of Alagoas had the highest proportion of this outcome $(27.2 \%)$, followed by the states of Pernambuco and Rio Grande do North, both with a prevalence of $25.8 \%$ (Figure 1).

According to Table 2, the highest prevalence of multimorbidity was observed in women (26.7\%), in those aged 80 and over (28.0\%), with low levels of education (24.4\%) and who were overweight $(28.1 \%)$. On the other hand, a higher prevalence of the outcome was found in older adults who did not consume tobacco $(24.8 \%)$ or alcohol $(25.6 \%)$. In the bivariate analysis, sex, age group, receiving a pension, marital status, self-reported skin color, body mass index, smoking and drinking were associated with the occurrence of multimorbidity due to chronic diseases in older adults (Table 2).

Table 3 shows that in the adjusted model, the factors associated with multimorbidity in the older adults were: sex, age group, skin color, BMI and alcoholism. Women were 33\% more likely to suffer multimorbidity than men (adjusted $\mathrm{OR}=1.33$; $p=0.002)$, regardless of age, skin color, BMI and alcohol consumption.

Longer-lived older adults, aged 80 or over, had a $35 \%$ greater chance of presenting the outcome (adjusted $\mathrm{OR}=1.35 ; p=0.019)$, than older adults aged 60 to 69 (Table 3). In addition, having brown skin/ being of mixed ethnicity was a protective factor for multimorbidity, when compared to being white (adjusted OR=0.79; $p=0.013$ ). Being overweight increased the chance of suffering multimorbidity by $37 \%$ (adjusted $\mathrm{OR}=1.37 ; p=0.001$ ). In contrast, being underweight (adjusted $\mathrm{OR}=0.71 ; p=0.017$ ), and current alcohol intake $(\mathrm{OR}=0.60 ; p<0.001)$, were considered protective factors for multimorbidity (Table 3). 
Table 1. Sociodemographic characterization of older participants $(n=3,394)$. States of the northeast region of Brazil, 2013.

\begin{tabular}{lll}
\hline Sociodemographic Characteristics & $\mathrm{n}(\%)$ & $\begin{array}{l}95 \% \text { confidence } \\
\text { interval }\end{array}$ \\
\hline Sex & $1,335(39.3)$ & $37.7-41.0$ \\
Male & $2,059(60.7)$ & $59.0-62.3$ \\
Female & & \\
Age group (years) & $1,858(54.7)$ & $53.0-56.4$ \\
$60-69$ & $1,075(31.7)$ & $30.1-33.2$ \\
$70-79$ & $461(13.6)$ & $12.5-14.8$ \\
80 or more & & \\
Retirement & $2,699(79.5)$ & $78.1-80.8$ \\
Yes & $695(20.5)$ & $19.1-21.9$ \\
No & $1,464(43.2)$ & $42.3-44.0$ \\
Marital status & $1,930(56.8)$ & $55.9-57.7$ \\
Partner & & \\
No partner & $1,118(32.9)$ & $31.4-34.5$ \\
Self-reported skin color & $1,866(55.0)$ & $53.3-56.6$ \\
White & $375(11.0)$ & $10.0-12.0$ \\
Mixed ethnicity & $35(1.1)$ & $0.07-0.14$ \\
Black & & \\
Other & $297(9.0)$ & $10.0-11.9$ \\
Schooling (years) & $366(10.8)$ & $79.1-81.8$ \\
12 or more & $2,731(80.5)$ & \\
9 to 11 & & \\
0 to 8 & &
\end{tabular}

Source: National Health Survey (or PNS), 2013.

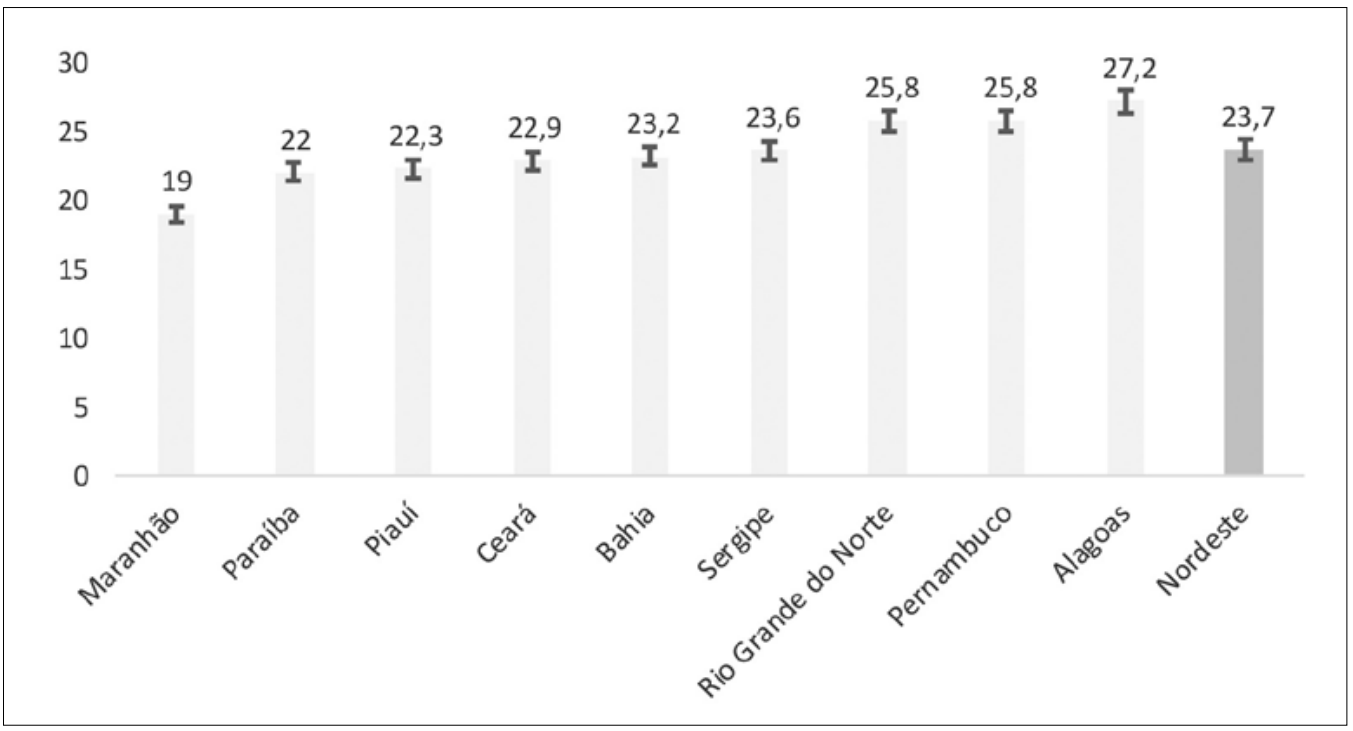

Figure 1. Prevalence of multimorbidity in older adults $(n=3,141)$, States of the northeast region of Brazil, 2013.

Source: National Health Survey (or PNS), 2013. 
Table 2. Association of sociodemographic, anthropometric and lifestyle factors and multimorbidity in older adults $(n=3,141)$. States of the northeast region of Brazil, 2013.

\begin{tabular}{|c|c|c|c|}
\hline \multirow{3}{*}{ Characteristics } & \multicolumn{2}{|c|}{ Multimorbidity } & \multirow[b]{3}{*}{ p-value } \\
\hline & No & Yes & \\
\hline & $\mathrm{n}(\%)$ & $\mathrm{n}(\%)$ & \\
\hline \multicolumn{4}{|l|}{ Sex } \\
\hline Male & $953(81.2)$ & $220(18.8)$ & $<0.001$ \\
\hline Female & $1443(73.3)$ & $525(26.7)$ & \\
\hline \multicolumn{4}{|l|}{ Age group (years) } \\
\hline 60 to 69 & $1344(78.4)$ & $371(21.6)$ & 0.006 \\
\hline 70 to 79 & $744(74.5)$ & $254(25.4)$ & \\
\hline 80 or over & $308(72.0)$ & $120(28.0)$ & \\
\hline \multicolumn{4}{|l|}{ Retired } \\
\hline Yes & $1883(75.4)$ & $615(24.6)$ & 0.019 \\
\hline No & $513(79.8)$ & $130(20.2)$ & \\
\hline \multicolumn{4}{|l|}{ Marital status } \\
\hline Partner & $1056(78.3)$ & $292(21.7)$ & 0.019 \\
\hline No partner & $1340(74.7)$ & $433(25.3)$ & \\
\hline \multicolumn{4}{|l|}{ Skin color } \\
\hline White & $780(73.6)$ & $280(26.4)$ & 0.006 \\
\hline Brown/mixed ethnicity & $1336(78.7)$ & $362(21.3)$ & \\
\hline Black/Afro-Brazilian & $257(73.6)$ & $92(26.4)$ & \\
\hline Other & $23(67.6)$ & $11(32.3)$ & \\
\hline \multicolumn{4}{|l|}{ Schooling (years) } \\
\hline 12 or more & $235(79.4)$ & $61(20.6)$ & 0.180 \\
\hline 9 to 11 & $284(78.7)$ & $77(21.3)$ & \\
\hline 0 to 8 & $1877(75.6)$ & $607(24.4)$ & \\
\hline \multicolumn{4}{|l|}{ BMI } \\
\hline Normal weight & $1024(78.1)$ & $287(21.9)$ & $<0.001$ \\
\hline Underweight & $419(83.1)$ & $85(16.9)$ & \\
\hline Overweight & $953(71.9)$ & $373(28.1)$ & \\
\hline \multicolumn{4}{|l|}{ Smoking } \\
\hline No & $2058(75.2)$ & $679(24.8)$ & $<0.001$ \\
\hline Yes & 338 (83.7) & $66(16.3)$ & \\
\hline \multicolumn{4}{|l|}{ Alcoholism } \\
\hline No & 1907 (74.4) & 657 (25.6) & $<0.001$ \\
\hline Yes & $489(84.7)$ & 88 (15.2) & \\
\hline \multicolumn{4}{|l|}{ Physical activity } \\
\hline Yes & $492(77.5)$ & $143(22.5)$ & 0.427 \\
\hline No & $1904(76.0)$ & $602(24.0)$ & \\
\hline \multicolumn{4}{|c|}{$\begin{array}{l}\text { Regular consumption (salad, fruits } \\
\text { and vegetables) }\end{array}$} \\
\hline Regular & $2112(76.2)$ & $660(23.8)$ & 0.743 \\
\hline Irregular & $284(77.0)$ & $85(23.0)$ & \\
\hline
\end{tabular}

Source: National Health Survey (or PNS), 2013. 
Table 3. Non-adjusted and adjusted odds ratios (OR) for the occurrence of multimorbidity according to sociodemographic characteristics, anthropometry and lifestyle in older adults $(n=3,141)$. States of the northeast region of Brazil, 2013.

\begin{tabular}{|c|c|c|c|c|}
\hline \multirow[b]{2}{*}{ Characteristics } & \multicolumn{4}{|c|}{ Multimorbidity } \\
\hline & $\begin{array}{l}\text { Non-adjusted } \\
\text { Odds Ratio } \\
(95 \% \mathrm{CI})\end{array}$ & $p$-value & $\begin{array}{l}\text { Odds Ratio } \\
\text { Adjusted } \\
(95 \% \mathrm{CI})\end{array}$ & $p$-value \\
\hline \multicolumn{5}{|l|}{ Sex } \\
\hline Male & Ref.*** & & Ref & \\
\hline Female & $1.57(1.31-1.88)$ & $<0.001$ & $1.33(1.10-1.61)$ & 0.002 \\
\hline \multicolumn{5}{|l|}{ Age group } \\
\hline 60 to 69 & Ref. & & Ref. & \\
\hline 70 to 79 & $1.23(1.02-1.48)$ & 0.023 & $1.17(0.97-1.42)$ & 0.083 \\
\hline 80 or more & $1.41(1.11-1.79)$ & 0.005 & $1.35(1.05-1.73)$ & 0.019 \\
\hline \multicolumn{5}{|l|}{ Retired } \\
\hline Yes & Ref. & & Ref. & \\
\hline No & $0.77(0.62-0.95)$ & 0.019 & - & - \\
\hline \multicolumn{5}{|l|}{ Marital status } \\
\hline Partner & Ref. & & Ref. & \\
\hline No partner & $1.22(1.03-1.44)$ & 0.019 & - & - \\
\hline \multicolumn{5}{|l|}{ Skin color } \\
\hline White & Ref. & & Ref. & \\
\hline Brown/mixed ethnicity & $0.75(0.63-0.90)$ & 0.002 & $0.79(0.66-0.95)$ & 0.013 \\
\hline Black/Afro-Brazilian & $0.99(0.75-1.31)$ & 0.984 & $1.05(0.80-1.40)$ & 0.685 \\
\hline Other & $1.33(0.64-2.76)$ & 0.442 & $1.31(0.62-2.75)$ & 0.469 \\
\hline \multicolumn{5}{|l|}{ Schooling (years) } \\
\hline 12 or more & Ref. & & Ref. & \\
\hline 9 to 11 & $1.04(0.71-1.52)$ & 0.821 & - & - \\
\hline 0 to 8 & $1.24(0.92-1.67)$ & 0.146 & - & - \\
\hline \multicolumn{5}{|l|}{ BMI } \\
\hline Normal weight & Ref. & & Ref. & \\
\hline Underweight & $0.72(0.55-0.94)$ & 0.018 & $0.71(0.54-0.94)$ & 0.017 \\
\hline Overweight & $1.39(1.16-1.66)$ & $<0.001$ & 1.37 (1.15- 1.65) & 0.001 \\
\hline \multicolumn{5}{|l|}{ Smoking } \\
\hline No & Ref. & & Ref. & \\
\hline Yes & $0.59(0.44-0.78)$ & $<0.001$ & - & - \\
\hline \multicolumn{5}{|l|}{ Alcoholism } \\
\hline No & Ref. & & Ref. & \\
\hline Yes & $0.52(0.40-0.66)$ & $<0.001$ & $0.60(0.43-0.78)$ & $<0.001$ \\
\hline
\end{tabular}

Source: National Health Survey (or PNS), 2013.

* Odds ratios of multimorbidity according to the individual explanatory variable with respective $95 \%$ Confidence Interval; ** Odds ratios of multimorbidity adjusted for all explanatory variables, with respective $95 \%$ Confidence Interval; ***Reference category for comparisons. 


\section{DISCUSSION}

In the present study the prevalence of two or more chronic diseases among older adults in the northeast region of Brazil was $23.7 \%$. In other Brazilian surveys, a range of prevalence of between $30.7 \%$ and $98 \%$ was found. This variation in the prevalence of multimorbidity may be due to the definition adopted for this outcome. For example, some studies define multimorbidity as the occurrence of three or more diseases. In addition, there are large variations in the samples used and contexts investigated ${ }^{6,1,20,20}$.

The state in the northeast with the highest prevalence of multimorbidity in older adults was Alagoas (27.22\%), a finding which may be related to socioeconomic issues, as this state has the worst Human Development Index in Brazil, and the second lowest household income per capita. In addition, 96.1\% of the municipalities are classified as having high or very high social vulnerability ${ }^{21}$.

Significant differences in the prevalence of multimorbidity were also observed according to sex, age group, pension, marital status, skin color, BMI, smoking and alcoholism, corroborating previous studies $^{22,23}$. In contrast, in the multiple model, only sex, age group, skin color, BMI and alcoholism remained associated with multimorbidity.

Women were more likely to develop multimorbidity than men. This finding was also observed in previous studies carried out with different populations and regions $^{22,23}$. Several factors can justify this fact. Firstly, biological aspects, related to the reduction of estrogen after menopause, a period in which women become more vulnerable to CNCDs, such as colon and breast cancer, strokes, thromboembolisms and type II diabetes mellitus $^{24}$. Secondly, gender aspects, as the growing presence of women in the labor market, when combined with chores assigned in the home, can generate a workload three times greater than that of men. This reality can contribute to a greater burden of these diseases in women ${ }^{25}$. In addition, women access health services more frequently. Thus, there may be greater notification of cases of NCDs, while for men there may be an underreporting, as they access health services less frequently, due to cultural and gender influences ${ }^{22,26}$.

There was also an association between age group and the occurrence of multimorbidity. Long-lived older adults were more likely to suffer multimorbidity than older adults aged 60 to 69 years. Previous studies have shown that long-lived older adults may suffer more impacts from the physiological, morphological, biochemical and psychological changes that occur with aging, which can linearly predispose them to functional decline and greater susceptibility to diseases $^{6,13,27}$.

In the present study, it was found that having brown skin/being of multiethnicity can reduce the chance of multimorbidity, in contrast to being white. Previous studies show that white individuals have a higher prevalence of abdominal adiposity and a greater abdominal perimeter, especially $\operatorname{men}^{6,28}$. In addition, previous research has shown that in the white-skinned population there is a higher consumption of tobacco products, associated with a lower consumption of fruits, vegetables, and lower caloric expenditure in labor functions, when compared to brown and black individuals ${ }^{6,28}$.

Another important result of this study was that overweight older adults have a 37\% greater chance of multimorbidity than eutrophic individuals. Obesity and overweight are predisposing conditions for CNCDs, such as: type II diabetes mellitus, arterial hypertension, cardiovascular diseases and cancer ${ }^{4,5,29}$. Lifestyle is one factor related to these conditions ${ }^{5,29}$.

An irregular diet in addition to physical inactivity can increase the chronic concentration of visceral adipose tissue, which together with the molecular changes associated with obesity are factors that trigger metabolic syndrome and compromise the homeostasis of several systems. In addition, when associated with aging, these factors may predispose the individual to the onset of disabilities and reduce quality of life $e^{4,5,29}$.

This study also found protective factors for the outcome, such as being underweight and current alcohol consumption. Low weight may be related to other conditions, including functional dependence 
and disability ${ }^{28}$. On the other hand, being overweight and obesity are strongly associated with CNCDs such as systemic arterial hypertension, diabetes mellitus and heart diseases ${ }^{11,22}$.

Alcohol consumption, investigated in this study, was related to consumption at the time of the survey and not in the past. The frequency and amount ingested by the older adults were also not considered, which may have influenced the association found. However, previous studies show that alcohol consumption in low doses and at low frequencies can be a protective factor for cardiovascular diseases ${ }^{28,29}$. In contrast, the reduction in the chance of multimorbidity with alcohol consumption evidenced in this study, may be due to a phenomenon that is influenced by the time frame, as cross-sectional studies have the limitation of obtaining information that refers to a single moment. It is known that the emergence of diseases can influence the reduction or cessation of alcohol consumption. On the other hand, the older adults may have consumed alcohol in the past, and therefore suffered exposure then ${ }^{22,30}$.

The consumption of alcohol in harmful doses is a recognized risk factor for multimorbidity ${ }^{7}$. Therefore, the goal in Brazil is to reduce its prevalence from $18 \%$ to $12 \%$ by the year 2022 . Alcohol consumption is related to the occurrence of various $\mathrm{CNCDs}$, such as neoplasms, liver diseases, chronic kidney disease and cardiovascular diseases ${ }^{4,7}$.

The results of this study have certain limitations. First, a self-reported multimorbidity metric was used, which can underestimate or overestimate prevalences. On the other hand, this form of measurement has

\section{REFERENCES}

1. Huguenin FM, Pinheiro RS, Almeida RMVR, Infantosi AFC. Characterization of the variation of health care taking into account the costs of hospital admissions for acute myocardial infarction in Brazilian Unified Health System. Rev Bras epidemiol [Internet]. 2016. [acesso em 05 abr 2019];19(2):229-42. Disponível em: https://www.scielo.br/scielo.php?script $=$ sci_ arttext\&pid=S1415-790X2016000200229 been used by Brazilian and international surveys, allowing comparisons ${ }^{6.7}$. Furthermore, the crosssectional structure makes it impossible to establish cause-effect relationships.

\section{CONCLUSION}

The prevalence of multimorbidity in older adults living in the community in the northeast region of Brazil, was almost a quarter of the population participating in this study, and Alagoas was the state with the highest proportion of older adults with two or more chronic diseases. The factors associated with the occurrence of multimorbidity were sex, age group and being overweight.

The identification of these factors is important for strengthening and expanding health promotion, prevention and surveillance strategies, as well as public policies, in order to provide a perspective focused on priority groups (women, octogenarians and overweight people) and on the states of the northeast region with the highest prevalence of multimorbidity, such as Alagoas.

It is vital to expand health care for older adults in a transversal manner in order to meet the needs of younger age groups, who will be the older adults of future generations. Finally, it is suggested that subsequent studies adopt longitudinal methodologies which reduce the effects of reverse causality and, thus, can ratify and expand the scope of knowledge about risk factors for multimorbidity in older adults.

Edited by: Ana Carolina Lima Cavaletti
2. World Health Organization. World health statistics 2018: monitoring health for the SDGs, sustainable development goals [Internet]. Geneva: WHO; 2018 [acesso 05 abr. 2019]. Disponível em: https://apps.who.int/iris/bitstream/hand le/10665/272596/9789241565585-eng.pdf?ua=1 
3. Malta DC, Andrade SSCA, Oliveira TP, Moura L, Prado RR, Souza MFM. Probability of premature death for chronic non-communicable diseases, Brazil and Regions, projections to 2025. Rev Bras Epidemiol [Internet].2019 [acesso em 15 abr. 2020];22(1):1-13. Disponível em: http://www.scielo.br/pdf/rbepid/ v22/1980-5497-rbepid-22-e190030.pdf

4. Malta DC, Campos MO, Oliveira MM, Iser BPM, Bernal RTI, Claro RM, et al. Noncommunicable chronic disease risk and protective factor prevalence among adults in Brazilian state capital cities, 2013. Epidemiol Serv Saúde [Internet]. 2015.[acesso em 06 abr. 2019];24(3):373-87. Disponível em: http://scielo.iec.gov.br/scielo.php?script=sci_ arttext\&pid=S1679-49742015000300004

5. Brasil. Ministério da Saúde. Plano de ações estratégicas para o enfrentamento das doenças crônicas não transmissíveis (DCNT) no Brasil 2011-2022. Brasília, DF: Ministério da Saúde; 2011 [acesso em 05 abr. 2019]. Disponível em: http://bvsms.saude.gov.br/bvs/ publicacoes/plano_acoes_enfrent_dcnt_2011.pdf

6. Harrison C, Henderson J, Miller G, Britt H. The prevalence of diagnosed chronic conditions and multimorbidity in Australia: a method for estimating population prevalence from general practice patient encounter data. Plos ONE [Internet]. 2017. [acesso em 15 abr 2019];12(3):1-13 Disponível em: https:// journals.plos.org/plosone/article?id=10.1371/journal. pone. 0172935

7. Stopa SR, Cesar CLG, Segri NJ, Aves MCGP, Barros MBA, Goldbaum M. Prevalence of arterial hypertension, diabetes mellitus, and adherence to behavioral measures in the city of São Paulo, Brazil, 2003-2015. Cad Saúde Pública [Internet]. 2018 [acesso em 07 abr. 2019];34(10):e00198717 [11 p.]. Disponível em: https://www.scielo.br/scielo.php?script=sci_ arttext\&pid=S0102-311X2018001005010

8. Moreira JPL, Almeida RMVR, Rocha NCS, Luiz RR. Prevalence of corrected arterial hypertension based on the self-reported prevalence estimated by the Brazilian National Health Survey. Cad Saúde Pública [Internet]. 2020 [acesso em 15 abr. 2020];36(1):e00033619 [9 p.]. Disponível em: https://www.scielo.br/scielo.php?script=sci_ arttext\&pid=S0102-311X2020000105014\&tlng=en

9. Cavalcante G, Doring M, Portella MR, Batoluzzi EC, Mascarelo A, Dellani MP. Multimorbidity associated with polypharmacy and negative self-perception of health. Rev Bras Geriatr Gerontol [Internet]. 2017 [acesso em 22 abr. 2019];20(5):634-42. Disponível em: https://www. scielo.br/scielo.php?script $=$ sci_arttext\&pid=S180998232017000500634\&lng=en\&tlng=en
10. Bernardes GM, Mambrini JVM, Lima-Costa MF, Peixoto SV. Perfil de multimorbidade associado à incapacidade entre idosos residentes na Região Metropolitana de Belo Horizonte, Brasil. Ciênc Saúde colet [Internet]. 2019 [acesso em 16 abr. 2020];24(5):1853-64. Disponível em: http://www. scielo.br/scielo.php?script $=$ sci_arttext\&pid $=$ S141381232019000501853\&lng=en

11. Geib LTC. Social determinants of health in the elderly. Ciênc Saúde Colet [Internet]. 2012 [acesso em 22 abr. 2019];17(1):123-33. Disponível em: https://www. scielo.br/scielo.php?script $=$ sci_arttext\&pid=S1413$81232012000100015 \& \operatorname{lng}=\mathrm{pt} \& \operatorname{lng}=\mathrm{pt}$

12. Szwarcwald CL, Malta DC, Pereira CA, Vieira MLFP, Conde WL, Souza Junior PRB, et al. National Health Survey in Brazil: designer and methodology of application. Ciênc Saúde Colet [Internet]. 2014. [acesso em 15 ab. 2019];19(2):333-42. Disponível em: http://www.scielo.br/scielo.php?script=sci_ arttext\&pid=S1413-81232014000200333

13. Freitas MPS. Pesquisa Nacional de Saúde: Plano amostral. Rio de Janeiro: IBGE; 2014.

14. Souza Junior PRB, Damacena GN, Swarcwald CL, Malta DC, Vieira MLFP. Desenho da amostra da Pesquisa Nacional de Saúde, 2013. Epidemiol Serv Saúde [Internet]. 2015 [acesso em 22 abr. 2019];24(2):207-16. Disponível em: http://www.scielo.br/scielo.php?pid=S223796222015000200197\&script $=$ sci_abstract\&tlng=pt

15. Kathryn N, Amanda LT, Martin FTW, Michael B, Amardeep T. Prevalence characteristics, and patterns of patients with multimorbidity in primary care: a retrospective cohort analysis in Canada. Br J Gen Pract [Internet]. 2019 [acesso em 15 abr. 2020];69(686):647-56. Disponível em: https://www. ncbi.nlm.nih.gov/pubmed/31308002

16. Brasil. Ministério da Saúde. Vigitel Brasil 2017 Vigilância de fatores de risco e proteção para doenças crônicas por inquérito telefônico. Brasília, DF: MS; 2018 [acesso em 22 abr.2019]. Disponível em: http://bvsms.saude.gov.br/bvs/publicacoes/vigitel_ brasil_2017_vigilancia_fatores_riscos.pdf

17. Instituto Brasileiro de Geografia e Estatística. Manual de Antropometria. Pesquisa Nacional de Saúde 2013 [Internet]. Rio de Janeiro: IBGE; 2013 [acesso em 22 abr. 2019]. Disponível em: https://www.pns. icict.fiocruz.br/arquivos/Novos/Manual $\% 20 \mathrm{de} \% 20$ Antropometria\%20PDF.pdf

18. Lipschitz DA. Screening for nutritional status in theelderly. Prim Care [Internet].1994 [acesso em 24 abr. 2019];21(1):55-67. Disponível em: https://www. ncbi.nlm.nih.gov/pubmed/8197257 
19. Mini GK, Thankappan KR, Pattern, correlates and implications of non-communicable disease multimorbidity among older adults in selected Indian states: a cross-sectional study. BMJ Open [Internet]. 2017 [acesso em 22 abr. 2019];7(3):e13529 [9 p.]. Disponível em: https://www.ncbi.nlm.nih.gov/ pubmed/28274966

20. Albuquerque MV, Vianna ALD, Lima LD, Ferreira MP, Fusaro ER, Iozzi FL. Regional health inequalities: changes observed in Brazil from 2000-2016. Ciênc Saúde Colet [Internet]. 2017 [acesso em 7 abr. 2019];22(4):1055-64. Disponível em: https://www. scielo.br/scielo.php?script $=$ sci_arttext\&pid=S1413$81232017002401055 \& \ln \mathrm{g}=\mathrm{pt} \& \mathrm{t} \operatorname{lng}=\mathrm{pt}$

21. Instituto de Pesquisa Econômica Aplicada. Atlas da Vulnerabilidade Social nos Municípios Brasileiros [Internet]. Brasília, DF: IPEA; 2015 [acesso em 15 abr. 2020]. Disponível em: http://ivs.ipea.gov.br/ images/publicacoes/Ivs/publicacao_atlas_ivs.pdf

22. Melo JB, Campos CA, Carvalho PC, Meireles MF, Andrade MVG, Rocha TPO, et al. Cardiovascular Risk Factors in Climateric Woman with Cononary Artery Disease. Int J Cardiovasc Sci [Internet]. 2018 [acesso em 5 maio 2019];31(1):4-11. Disponível em: http://www.scielo.br/pdf/ijcs/v31n1/pt_2359-4802ijcs-20170056.pdf

23. Nunes BP, Batista SRR, Andrade FB, Souza PRB, Lima-Costa MF, Fachinni A. Multimorbidity: the Brazilian Longitudinaç Study of Aging (ELSIBRAZIL). Rev Saúde Pública [Internet]. 2018 [acesso em 04 maio 2019];52(2):1-12. Disponível em: https://www.scielo.br/scielo.php?script=sci_ arttext\&pid=S0034-89102018000300509

24. Pardini D. Hormone replacement therapy in menopause. Arq Bras Endocrinol Metab [Internet]. 2014 [acesso em 12 maio 2019];58(2):1-10. Disponível em: https://www.scielo.br/pdf/abem/v58n2/00042730-abem-58-2-0172.pdf

25. Carneiro JA, Cardoso RR, Durães MS, Guedes MCA, Santos FL, Costa FM, et al. Frailty in the elderly: prevalence and associated factors. Rev Bras Enferm [Internet]. 2017 [acesso em 12 maio 2019];70(4):747-52. Disponível em: https://www. scielo.br/scielo.php?script $=$ sci_arttext\&pid $=$ S0034$71672017000400747 \& \operatorname{lng}=$ en\&tlng=en
26. Bernardes GM, Mambrini JVM, Lima-Costa MF, Peixoto SV. Multimorbidity profile associated with disability among older adults living in the Metropolitan Region of Belo Horizonte. Ciênc Saúde Colet [Internet]. 2018 [acesso em 08 abr. 2019]. Disponível em: http://www.cienciaesaudecoletiva. com.br/artigos/perfil-de-multimorbidade-associadoa-incapacidade-entre-idosos-residentes-na-regiaometropolitana-de-belo-horizonte/16951?id=16951

27. Sousa KT, Mesquita LAS, Pereira LA, Azevedo $\mathrm{CM}$. Low weight and functional disability in institutionalized elderly interns in Uberlândia in the State of Minas Gerais, Brazil. Ciênc Saúde Colet [Internet]. 2014 [acesso em 13 abr. 2019];19(8):3513-20. Disponível em: http://www.scielo.br/scielo.php?script=sci_ arttext\&pid $=$ S1413-81232014000803513

28. Gaetano G, Costango S, Di Castelnuovo A, Badmon L, Bejko D, Alkerwi A, et al. Effects of moderate beer consumption on health and disease: a consensus document [Internet]. 2016 [acesso em 12 maio 2019];26(6):443-67. Disponível em: https://www.ncbi. nlm.nih.gov/pubmed/27118108

29. Chiva BG, Magraner E, Condenes X, Valderas Martinez P, Roth I, Arranz S, et al. Effects of alcohol and polyphenols from beer on atherosclerotic biomarkers in high cardiovascular risk men: a randomized feeding trial. Nutr Metab Cardiovasc Dis [Internet]. 2016 [acesso em 12 maio 2019];25(1):3645. Disponível em: https://www.sciencedirect.com/ science/article/abs/pii/S0939475314002518

30. Jorge MSG, Lima WG, Vieira PR, Vogelmann SC, Myra RS, Wibelinger LM. Social and demographc profile, health conditions and social conditions of over-eighty elderly people. Saúde Pesqui [Internet]. 2017 [acesso em 12 maio 2019];10(1);61-73. Disponível em: https://periodicos.unicesumar.edu.br/index.php/ saudpesq/article/view/5822 